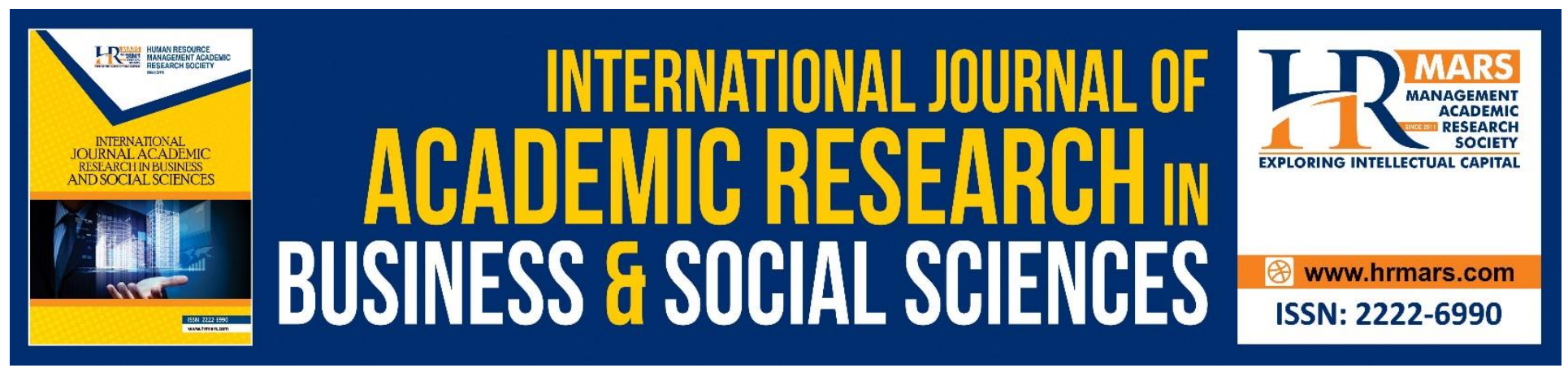

\title{
Gender Differences in Students' Satisfaction and Intention to the Continuation of Online Distance Learning
}

Siti Aishah Mohamad, Hasnizawati Hashim, llyani Azer, Hamnah Che Hamzah \& Rozieana A. Halid @ Khalid

To Link this Article: http://dx.doi.org/10.6007/IJARBSS/v10-i9/7855 DOI:10.6007/IJARBSS/v10-i9/7855

Received: 08 June 2020, Revised: 11 July 2020, Accepted: 15 August 2020

Published Online: 28 September 2020

In-Text Citation: (Mohamad, et. al, 2020)

To Cite this Article: Mohamad, S. A., Hashim, H., Azer, I., Hamzah, H. C., \& Khalid, R. A. H@. (2020). Gender Differences in Students' Satisfaction and Intention to the Continuation of Online Distance Learning. International Journal of Academic Research in Business and Social Sciences. 10(9), 641-650.

Copyright: (C) 2020 The Author(s)

Published by Human Resource Management Academic Research Society (www.hrmars.com)

This article is published under the Creative Commons Attribution (CC BY 4.0) license. Anyone may reproduce, distribute, translate and create derivative works of this article (for both commercial and non-commercial purposes), subject to full attribution to the original publication and authors. The full terms of this license may be seen

at: http://creativecommons.org/licences/by/4.0/legalcode

Vol. 10, No. 9, 2020, Pg. 641 - 650

http://hrmars.com/index.php/pages/detail/IJARBSS

JOURNAL HOMEPAGE

Full Terms \& Conditions of access and use can be found at http://hrmars.com/index.php/pages/detail/publication-ethics 


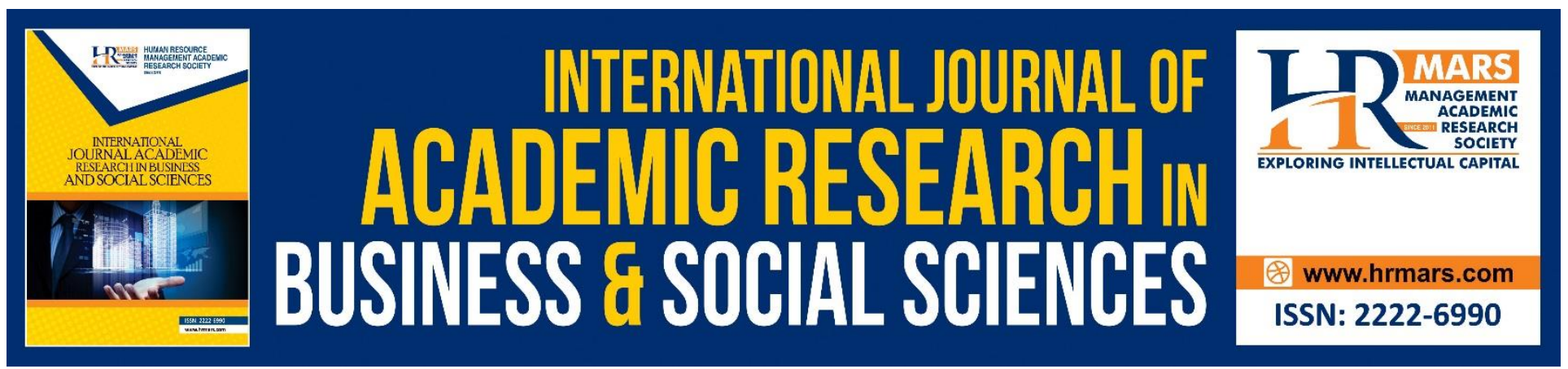

\title{
Gender Differences in Students' Satisfaction and Intention to the Continuation of Online Distance Learning
}

\author{
Siti Aishah Mohamad'1 Hasnizawati Hashim, llyani Azer², Hamnah \\ Che Hamzah \& Rozieana A. Halid @ Khalid \\ 1,2Universiti Teknologi MARA Pahang, Jengka Campus, Pahang, Malaysia \\ Universiti Teknologi MARA Pahang, Raub Campus, Pahang, Malaysia
}

\begin{abstract}
The COVID-19 pandemic has changed the educational landscape of Malaysia. The government's drastic action to implement the Movement Control Order (MCO) has forced all institutions of higher learning (IsHL) and schools to temporarily shut down. Learning activities had to continue, so online classes have been set up. Academicians and students have to adapt to the new learning environment. In Universiti Teknologi MARA (UITM), Online Distance Learning (ODL) was implemented. The drastic change has become a challenge specifically to students. After three months of implementing online learning, students gave positive and negative feedback on their new norms of learning. Hence, this study was conducted to investigate the difference between students' satisfaction and intention to the continuation of ODL based on gender perspective. Besides, this study also aims to assess the challenges faced by students in ODL. A survey was conducted, and SPSS 26.0 was used to analyze the data. The result found that there is no significant difference in satisfaction, and intention to continue usage of ODL among male and female students. This study also revealed that slow internet coverage was the biggest challenge among students in ODL. The finding of this study is expected to contribute to the academicians, policymakers and IsHL to take into account the problems faced by students when implementing the new method of teaching and learning.
\end{abstract}

Keywords: Online Distance Learning, Satisfaction, Intention, Gender, Challenges

\section{Introduction}

The COVID-19 pandemic has changed the educational landscape of Malaysia. The government's drastic action to implement the movement control order (MCO) has forced institutions of higher learning (IsHLs) and schools to shut down. Learning activities need to continue so online classes have been set up drastically. All the IsHL needed to urgently decide on the method of online learning that suited their students. Academicians and students have to adapt to the new learning environment. At Universiti Teknologi MARA (UiTM), Online Distance Learning (ODL) was implemented. The method of ODL during MCO was unexpected and unplanned. The academicians 
INTERNATIONAL JOURNAL OF ACADEMIC RESEARCH IN BUSINESS AND SOCIAL SCIENCES Vol. 10, No. 9, 2020, E-ISSN: 2222-6990 @ 2020 HRMARS

had to find and learn the online medium of teaching in a short period such as Learning Management System (LMS) that includes the platforms of Google Classroom, u-future, i-Learn, Microsoft Team, and Socrative. The academicians also chose social media such as Telegram, Facebook, WhatsApp, Instagram, YouTube, and Twitter as alternative platforms of teaching. Academicians and students were compelled to follow this form of learning and continue to learn for the remaining semesters.

Some of the UiTM students were familiar with online learning because blended learning and massive online open courses (MOOCs) had already been practised. In practising blended learning or MOOCs, the students can still meet lecturers and classmates and attend classes conducted at UiTM. During MCO, classes were held at the learners' houses. The students needed to cooperate to make the ODL class successful. Some of them were excited to learn because this new method of learning is flexible and convenient (Allam et al., 2020; Shailendra et al.,2018). For first-timers, both students and academicians encountered many challenges. The challenges can be in the forms of the system, users, infrastructure, and environment. Different countries are facing different challenges and so it has pushed this study to be conducted to find the challenges of ODL among UiTM students in Pahang.

There have been many studies of online learning previously. However, very limited number of research was carried out specifically on ODL due to disease outbreak highlighting on students' satisfaction and intention to continue the usage. In a normal situation, ODL benefits students and IsHL, thus creating high satisfaction and driving many users to continue with this online learning method. Gender has also played a role in this issue because few studies found that male learners were more satisfied than females with online learning, whereas others stated the opposite. Due to the inconsistent results, this study is carried out to identify the satisfaction and intention to continue the use of ODL among UiTM Pahang students in relation to gender.

\section{Literature Review}

The concept of ODL can be defined as a teaching method that fully utilises the internet network and easy access through a computer or mobile phone, which allows students to not physically attend the lecture session (Kenny, 2010; Hussin et al., 2017). This learning method has many advantages to IsHL, academicians, and students. Cost-saving is the main benefit of ODL to IsHL. For academicians and students, ODL may save time and cost because it is flexible and convenient. Despite the advantages, users are also facing challenges dealing with ODL.

The challenges facing effective online learning in Malaysia and Pakistan are access to the internet and internet-enabled devices (Rachel, 2020; Shahmoradi et al. 2018). The internet is the basic facility needed to implement online learning smoothly (Yusuf \& Ahmad, 2020). A recent study in China found that students often had a problem related to self-discipline, learning materials, and learning environment when they were self-isolated at home (Bao, 2020). From the view of students in South Korea, the need to adapt new pedagogical skills, self- motivation, and self -discipline has become the challenges in online learning (Cantoni, Cellario, \& Porta, 2004). According to Allam et al. (2020), during MCO, students face difficulty to start their learning activities at home without physical and social interactions with lecturers and group mates.

The challenges in learning will affect the satisfaction level and intention to use online learning (Barreto, Vasconcelos \& Orey, 2017; Drennan, Kennedy, \& Pisarski, 2005; Kenny, 2003; Carr, 2000). Wu, Tennyson, and Hsia (2010) defined satisfaction as obtaining all the benefits that learners want from learning according to their behavioural beliefs and attitudes. One research in India found that online learning increased students' satisfaction level in the study (Maheshwari et al., 2015). Knowing 
that the level of satisfaction with the system relates to technology, this contributes towards determining the effectiveness of the system. High level of satisfaction among students will motivate them to continue using technology in learning (Au, Ngai, \& Cheng, 2002; Baroudi, Olson, \& Ives, 1986). According to Bolliger and Wasilik (2009), perceived satisfaction was regarded as a critical part of continuous learning. Research into the information system indicated that customer satisfaction is one of the most significant factors in determining programme implementation performance and ensuring programme continuity (Hossain et al., 2020; Wafa, 2012; Chiu, Chiu, \& Chang, 2007; Shin \& Chan, 2004). Salma (2019), in her study, found that female and male students have different satisfaction levels. Most literature on the adoption of e-learning applications emphasised that gender was a significant factor (Goswami \& Dutta, 2016). However, some studies concluded that gender did not affect satisfaction towards e-learning (Cuadrado et al., 2010; Hung et al., 2010)

The previous research findings on the intention to continue the use of online learning were not consistent. The result from the study conducted by Abbasi et al. (2020) found that students preferred to choose e-learning to continue their studies. This finding contradicts with the study conducted at a private medical college in Pakistan, where the students were not ready and did not prefer online learning as compared to face-to-face learning (Ali et al., 2016). The intention to continue the use of technology was also influenced by gender. This finding is based on the previous research conducted by Raman et al. (2014) in Malaysia, who found that female students intended to use technology more than males. A similar conclusion was made by Egbo et al. (2011) in their study in Nigeria. However, few studies revealed that no gender difference was found in using online learning (Suri \& Sharm, 2013; Goswami \& Dutta, 2016). The gender inequality studies would contribute towards the development of technologies if the reasons behind it were revealed.

\section{Research Methodology}

The research conducted was explorative in nature, which was based on the ODL applied to UiTM Pahang students during MCO. Coherently, students from different faculties were involved. In particular, the samples were different in terms of educational level (pre-higher educational level, diploma, and degree) and the types of teaching applied - which was based on the faculty's requirement. The study targeted final-year students of semester four and five to be involved as the study samples. These final-year students were presented with some interesting aspects of the ordinary way of how teaching and learning were applied. These students were used in regular faceto-face methods of teaching in class as well as exposure to university academic requirements such as continuous assessments, tests, and quizzes. Online survey data were collected from 19 programs of study from 8 faculties during the students' final week of study (Week 14), and they were encouraged to take the survey voluntarily.

A five-point Likert scale from strongly disagree to strongly agree was used. There were about 12 variables in describing "Satisfaction" and "Intention to Continue Usage of ODL" factors. Together with these scaling questions, students also needed to answer "Yes" or "No" questions, which were related to the challenges that they encountered during ODL. The sample size was sufficient to conduct the analysis (Sekaran \& Bougie, 2010; Darwish, Abdo, \& AlShuwaiee, 2018). In this study, a T-test was applied to examine the proposed hypotheses. The SPSS 26.0 was used to run the analysis.

The survey consisted of two parts; Part A - Yes/No questions (Challenges encountered during $\mathrm{ODL}$ ) and Part B - Likert-scale questions (Satisfaction and Intention to Continue Usage of ODL). The full range of items pertaining to the satisfaction and intention to continue usage of ODL is 
INTERNATIONAL JOURNAL OF ACADEMIC RESEARCH IN BUSINESS AND SOCIAL SCIENCES Vol. 10, No. 9, 2020, E-ISSN: 2222-6990 @ 2020 HRMARS

demonstrated in Table 1. The table depicts the survey items incorporated in the questionnaire with the respective scales of measurement.

Table 1. Lists of Items and the Measurement Levels

\begin{tabular}{|c|c|c|c|}
\hline $\begin{array}{l}\text { Factors (Adopt } \\
\text { and Adapt) }\end{array}$ & $\begin{array}{l}\text { Item } \\
\text { Coding }\end{array}$ & Survey Items & $\begin{array}{l}\text { Measurement } \\
\text { Levels }\end{array}$ \\
\hline \multirow{6}{*}{$\begin{array}{l}\text { Satisfaction } \\
\text { (Hong et al., } \\
2006 \text { ) }\end{array}$} & SAT1 & ODL is effective for knowledge exchange. & \multirow[t]{6}{*}{ Ordinal $(1-5)$} \\
\hline & SAT2 & ODL helps to increase understanding in learning. & \\
\hline & SAT3 & ODL makes me happy while studying. & \\
\hline & SAT4 & ODL facilitates interaction with lecturers. & \\
\hline & SAT5 & ODL allows me to learn at flexible times. & \\
\hline & SAT6 & ODL provides overall learning satisfaction. & \\
\hline \multirow{6}{*}{$\begin{array}{l}\text { Intention to } \\
\text { Continue } \\
\text { Usage of ODL } \\
\text { (Hong et al., } \\
\text { 2006) }\end{array}$} & INT1 & I will look forward to using ODL in the future. & \multirow[t]{6}{*}{ Ordinal $(1-5)$} \\
\hline & INT2 & $\begin{array}{l}\text { I plan to continue using ODL method next } \\
\text { semester. }\end{array}$ & \\
\hline & INT3 & $\begin{array}{l}\text { I plan to use ODL method for higher levels of } \\
\text { study. }\end{array}$ & \\
\hline & INT4 & $\begin{array}{l}\text { I plan to increase the use of ODL by using more } \\
\text { platforms. }\end{array}$ & \\
\hline & INT5 & $\begin{array}{l}\text { I will encourage family members to study through } \\
\text { ODL. }\end{array}$ & \\
\hline & INT6 & I would encourage friends to study through ODL. & \\
\hline
\end{tabular}

The reliability of the constructs was assessed using Cronbach's $\alpha$. A value of 0.70 is considered satisfactory for most studies (Nunnally, 1978). The reliability of the 12 items in this study was found to be more than the threshold, which showed good reliability (Table 2 ).

Table 2. Reliability Analysis

\begin{tabular}{|l|l|l|}
\hline Constructs & Items & Cronbach's $\boldsymbol{\alpha}$ \\
\hline Satisfaction & 6 & 0.915 \\
\hline Intention to Continue Usage of ODL & 6 & 0.942 \\
\hline
\end{tabular}

\section{Results and Discussion}

This section deliberates on the results of the empirical testing of the data gathered. The first part will discuss on the students' demographic profile, followed by the discussion on challenges determined by various steps on the test conducted with regard to the T-tests. The final survey data included 742 responses, of which $70 \%$ were from female students, and $67.8 \%$ were from the Diploma level, which exactly depicted the reality of the overall population of UiTM Pahang students. Among the respondents, 52.2\% were from urban areas. Furthermore, the details of the respondents' programme based on backgrounds are shown in Table 3. 
INTERNATIONAL JOURNAL OF ACADEMIC RESEARCH IN BUSINESS AND SOCIAL SCIENCES

Vol. 10, No. 9, 2020, E-ISSN: 2222-6990 @ 2020 HRMARS

Table 3. List of Respondents' Levels and Programmes of Study

\begin{tabular}{|c|c|c|}
\hline Programmes of Study & $\begin{array}{l}\text { Number of } \\
\text { respondents }\end{array}$ & $\begin{array}{l}\text { Percentage } \\
\text { (\%) }\end{array}$ \\
\hline \multicolumn{2}{|l|}{ Pre-Diploma } & 2.7 \\
\hline 1) Pre-Diploma of Commerce (BA002) & 20 & 2.7 \\
\hline \multicolumn{2}{|l|}{ Diploma } & 67.8 \\
\hline 1) Diploma of Accounting (AC110) & 69 & 9.3 \\
\hline 2) Diploma of Wood Industry (AS117) & 8 & 1.1 \\
\hline 3) Diploma of Planting Management (AT110) & 24 & 3.2 \\
\hline $\begin{array}{l}\text { 4) Diploma of Office Technology and Management } \\
\text { (BM118) }\end{array}$ & 178 & 24.0 \\
\hline $\begin{array}{l}\text { 5) Diploma of Sports Management and Recreation } \\
\text { (SR113) }\end{array}$ & 69 & 9.3 \\
\hline 6) Diploma of Civil Engineering (EC110) & 57 & 7.7 \\
\hline 7) Diploma of Banking Studies (BM119) & 13 & 1.8 \\
\hline 8) Diploma of Computer Science (CS110) & 36 & 4.9 \\
\hline 9) Diploma of Statistic (CS111) & 0 & 0.0 \\
\hline 10) Diploma of Business Studies (BM111) & 45 & 6.1 \\
\hline 11) Diploma of Public Administration (AM110) & 5 & 0.7 \\
\hline \multicolumn{2}{|l|}{ Bachelor } & 29.5 \\
\hline 1) Bachelor of Wood Technology (AS247) & 71 & 9.6 \\
\hline 2) Bachelor in Office System Management (BA232) & 41 & 5.5 \\
\hline $\begin{array}{l}\text { 3) Bachelor of Sports Management and Recreation } \\
\text { (SR243) }\end{array}$ & 8 & 1.1 \\
\hline 4) Bachelor of Science (Biodiversity Management) (AS255) & 18 & 2.4 \\
\hline 5) Bachelor of Science (Biology) (AS201) & 32 & 4.3 \\
\hline 6) Bachelor of Science (Chemistry) (AS202) & 11 & 1.5 \\
\hline 7) Bachelor of Science (Physics) (AS203) & 37 & 5.0 \\
\hline Total & 742 & 100.0 \\
\hline
\end{tabular}

Table 4 shows the means and standard deviations for Satisfaction and Intention to Continue Usage of ODL constructs. It is found that most students were low inclination in both constructs, as indicated by the means and standard deviation values. All constructs were tallied with a low mean (Satisfaction; 2.52 and Intention to Continue Usage of ODL; 2.53) and followed by a low standard deviation. It can be well said that the students were not satisfied with their ODL. Besides, they did not have the intention to continue using ODL in the future.

Table 4. Means and Standard Deviation for Constructs

\begin{tabular}{|l|c|c|c|c|c|}
\hline Constructs & N & Valid & Missing & Mean & $\begin{array}{c}\text { Std. } \\
\text { Deviation }\end{array}$ \\
\hline Satisfaction & 742 & 742 & 0 & 2.52 & 0.87 \\
\hline Intention to Continue Usage of ODL & 742 & 742 & 0 & 2.53 & 0.97 \\
\hline
\end{tabular}


INTERNATIONAL JOURNAL OF ACADEMIC RESEARCH IN BUSINESS AND SOCIAL SCIENCES Vol. 10, No. 9, 2020, E-ISSN: 2222-6990 @ 2020 HRMARS

Table 5 depicts the challenges encountered by the students during ODL, which contributed towards the low mean of their satisfaction and intention to continue the usage of ODL. The results revealed that there were three significant challenges that influenced students' ODL. Slow internet coverage (64.9\%) was found to be the biggest challenge among students, followed by the inconducive study environment (62.4\%) and lack of family support (51.8\%). Conversely, the results showed that most of the students did not have problems owning any suitable devices in applying ODL. This factor was illustrated by the view of only $11.6 \%$ of the students selecting this factor as their challenge. This finding was expected as most of these students own a smartphone and other devices such as a personal computer. Owning these devices are perceived as important in pursuing their daily life nowadays. Hence, to be proficient in technology and its application were not the main problem in ODL implementation for them.

Table 5. Challenges Encountered During ODL

\begin{tabular}{|l|c|c|}
\hline Challenges & Yes (\%) & No (\%) \\
\hline 1. Lack of tolerance from lecturers. & 16.1 & 80.7 \\
\hline 2. Difficulty to access the system/application. & 12.0 & 88.0 \\
\hline 3. System/application used is not user-friendly. & 18.1 & 78.6 \\
\hline 4. System/application used always hang. & 36.1 & 60.7 \\
\hline 5. Slow internet coverage. & 64.9 & 31.6 \\
\hline 6. Lack of support from family. & 51.8 & 45 \\
\hline 7. Inconducive study environment. & 62.4 & 34.2 \\
\hline 8. No suitable device to study using ODL. & 11.6 & 85.1 \\
\hline 9. Others & 14.9 & 81.9 \\
\hline
\end{tabular}

The T-test results for the constructs are shown in Table 6. There were no significant differences found at the $p<0.05$ between genders and the constructs of satisfaction $(p=0.996)$ and intention to continue usage of ODL $(p=0.684)$. It is shown that there was no significant difference in the satisfaction rate towards using ODL among males (Mean= 2.5188, SD=0.9578) and females (Mean=2.5184, SD=0.8371). Besides, there was no significant difference between gender and the constructs of intention to continue usage of ODL among males (Mean=2.3176, SD=1.0455) and females (Mean=2.3492, SD=0.930). Based on the results, it is shown that females had a slightly higher mean value than male students in the intention to continue usage of ODL constructs. However, the difference in these mean values was not considered significant at only 0.05 level of confidence.

Table 6. T-test Results for Gender Differences

\begin{tabular}{|l|c|c|c|}
\hline Constructs & Male & Female & Sig (2-tailed) \\
\hline Satisfaction & 2.5188 & 2.5184 & 0.996 \\
\hline Intention to Continue Usage of ODL & 2.3176 & 2.3492 & 0.684 \\
\hline
\end{tabular}

The results pointed to the conclusion that there was no significant difference in satisfaction, and intention to continue usage of ODL among male and female students. This finding is consistent with the study conducted by Hung et al., (2010) and Goswami and Dutta (2016). The challenges can be the factors that influence the satisfaction and intention of UiTM students to continue usage of ODL. The factors such as internet coverage, study environment and family support can be 
INTERNATIONAL JOURNAL OF ACADEMIC RESEARCH IN BUSINESS AND SOCIAL SCIENCES

Vol. 10, No. 9, 2020, E-ISSN: 2222-6990 @ 2020 HRMARS

investigated in future research as antecedents that influence the students' satisfaction and intention to continue usage of ODL.

\section{References}

Allam, S. N. S., Hassan, M. S., Mohideen, R. S., Ramlan, A. F., \& Kamal, R. M. (2020). Online Distance Learning Readiness During Covid-19 Outbreak Among Undergraduate Students. International Journal of Academic Research in Business and Social Sciences, 10 (5), 642657.

Ali, N., Jamil, B., Sethi, A., \& Ali, S. (2016) Attitude of nursing students towards e- learning. Adv Health Prof Educ. 2:24-29.

Abbasi, S., Ayoob, T., Malik, A., \& Memon, SI. (2020). Perceptions of students regarding E-learning during Covid-19 at a private medical college. Pak J Med Sci. 2020;36 (COVID19-S4): COVID19-S57-S61.

Bao, W. (2020). COVID-19 and online teaching in higher education:A case study of Peking University. Human Behaviour \& Emergence Technology. 2020;2:113-115.

Barreto, D., Vasconcelos, L., \& Orey, M. (2017). Motivation and learning engagement through playing math video games. Malaysian Journal of Learning and Instruction (MJLI), 14 (2), 1-21.

Bolliger, D. U., \& Martindale, T. (2004). Key factors for determining student satisfaction in online courses. International Journal on E-Learning, 3(1), 61-67.

Cantoni, V., Cellario, M., \& Porta, M. (2004). Perspectives and challenges in e learning: Towards natural interaction paradigms. Journal of Visual Languages and Computing, 15,333-345.

Carr, S. (2000). As distance education comes of age, the challenge is keeping the students. Chronicle of Higher Education, 46 (23), 39-41.

Chiu, C-M., Chiu, C-S., \& Chang, H.-C. (2007). Examining the integrated influence of fairness and quality on learners' satisfaction and Web-based learning continuance intention. Information Systems Journal, 271-287.

Cuadrado-García, M., Ruiz-Molina, M. E., \& Montoro-Pons, J. D. (2010). Are there gender differences in e-learning use and assessment? Evidence from an inter university online project in Europe. Procedia Social and Behavioral Sciences, 2(2), 367-371.

Darwish, S., Abdo, H., \& AlShuwaiee, W. M. (2018). Opportunities, challenges and risks of transition into renewable energy: the case of the Arab Gulf Cooperation Council. International Energy Journal, 18(4).

Drennan, J., Kennedy, J., \& Pisarski, A. (2005). Factors affecting student attitudes toward flexible online learning in management education. The Journal of Educational Research, 98(6), 331-338.

Egbo, O. P., Okoyeuzu, C. R., Ifeanacho, I. C., \& Onwumere, J. U. (2011). Gender perception and attitude towards e- learning: a case of business students, University of Nigeria. International Journal of Computer Application, 1, 135- 148.

Goswami, A. \& Dutta, S. (2016). Gender Differences in Technology Usage-A Literature Review. Open Journal of Business and Management, 4, 51-59.

Hong S. J., Thong J. Y. L., \& Tam, K. Y. (2006). Understanding continued information technology usage behavior: A comparison of three models in the context of mobile internet. Decision

Support Systems, 42(3), 1819-1834. doi:10.1016/j.dss.2006.03.009. 
INTERNATIONAL JOURNAL OF ACADEMIC RESEARCH IN BUSINESS AND SOCIAL SCIENCES

Vol. 10, No. 9, 2020, E-ISSN: 2222-6990 @ 2020 HRMARS

Hossain, M. N., Talukder, M. S., Khayer, A., \& Bao, Y. (2020), "Investigating the factors driving adult learners' continuous intention to use M-learning application: a fuzzy-set analysis", Journal of Research in Innovative Teaching \& Learning, Vol. ahead-of-print No. ahead-ofprint.

Hung, M. L., Chou, C., Chen, C. H., \& Own, Z. Y. (2010). Learner readiness for online learning: scale development and student perceptions. Computers \& Education, 55, 1080- 1090.

Kenny, Z. Z., \& R. F. (2010). Learning In An Online Distance Education Course: Experiences Of Three International Students. International Review of Research in Open and Distance Learning, 11(1), 18-36.

Kenny, J. (2003). Student perceptions of the use of online learning technology in their courses. ultiBase Articles. Retrieved from http://ultibase.rmit.edu.au /Articles/march03/kenny2.pdf.

Luyt, I. (2013). Bridging spaces: Cross-cultural perspectives on promoting positive online learning experiences. Journal of Educational Technology Systems,42, 3-20.

Maheshwari, S., Zheleva, B., Rajasekhar, V., \& Batra, B. (2015). e-Teaching in pediatric cardiology:A paradigm shift. Ann Pediatr Cardiol. 8(1):10-13. doi:10.4103/0974-2069.149512.

Mayes, R., Luebeck, J., Yu Ku, H., Akarasriworn, C., \& Korkmaz, O. (2011). Themes and strategies for transformative online instruction. The Quarterly Review of Distance Education,12, 151-166.

Nunnally, J. (1978). Psychometric theory. New York, NY: McGraw Hill.

Rachel G. (2020). Coping with Covid-19: Distance Learning and the Digital Divide. Khazanah Research Institute. Khazanah Research Institute Views $21 / 20$.

Raman, A., Don, Y., Khalid, R., \& Rizuan, M. (2014). Usage of Learning Management System (Moodle) among Postgraduate Students: UTAUT Model. Asian Social Science, 10, 186195. http://dx.doi.org/10.5539/ass.v10n14p186.

Sekaran U., \& Bougie, R. (2010). Research Methods for Business: A Skill Building Approach (5th ed.). West Sussex, UK: John Wiley \& Sons Ltd.

Shahmoradi, L., Changizi, V., Mehraeen, E., Bashiri, A., Jannat, B., \& Hosseini, M. (2018). The challenges of E-learning system: Higher educational institution's perspective. Journal of education and health promotion, 7, 116. https://doi.org/10.4103/jehp.jehp_39_18.

Shailendra P., Prageet A., Parul G., Diptiranjan M., Ratri P., Rebecca R., \& Sumita S. (2018). Online Education: Worldwide Status, Challenges, Trends, and Implications, Journal of Global Information Technology Management, 21:4, 233-241, doi: 10.1080/1097198X.2018.1542262.

Shin, N., \& Chan, J. (2004). Direct and indirect effects of online learning on distance education. British Journal of Educational Technology, 35(3), 275-288.

Suri, G., \& Sharma, S. (2013). The impact of gender on attitude towards computer technology and e-learning: an exploratory study of Punjab University, India. International Journal of Engineering Research, 2, 132-136.

Ali, W. G. M. (2012). Factors Affecting Nursing Student's Satisfaction with E- Learning Experience in King Khalid University, Saudi Arabia. International Journal of Learning \& Development, Vol. 2, No. 2. ISSN 2164-4063. 
INTERNATIONAL JOURNAL OF ACADEMIC RESEARCH IN BUSINESS AND SOCIAL SCIENCES

Vol. 10, No. 9, 2020, E-ISSN: 2222-6990 @ 2020 HRMARS

Wu, J. H., Tennyson, R. D., \& Hsia, T. L. (2010). A study of student satisfaction in a blended elearning system environment. Computers \& Education, 55(1), 155-164. doi:10.1016/j.compedu.2009.12.012.

Yusuf, B. N. M., \& Ahmad, J. (2020) Are we Prepared Enough? A Case Study Of Challenges In Online Learning In A Private Higher Learning Institution During The Covid-19 Outbreaks. Advances in Social Sciences Research Journal, 7(5) 205-212.

\section{Corresponding Author}

Siti Aishah Mohamad, UiTM Pahang, Malaysia, sitiajengka@gmail.com 